\title{
Admiral Furman Academy: A Case Study In Selected Not-For-Profit Auditing Issues
}

Frank J. Grippo, William Paterson University, USA

Sia Nassiripour, William Paterson University, USA

\begin{abstract}
The purpose of this case is to help students explore accounting and auditing issues often confronted by auditors of not-for-profit organizations. Given final financial statements, the goal of the case is to require students to prepare the footnotes that would be considered an integral part of the financial statements. The case is intended for students who are taking an advanced accounting or not-for-profit accounting course.
\end{abstract}

\section{BACKGROUND}

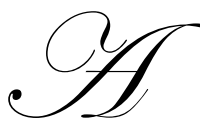

dmiral Furman Academy is a private male military college preparatory high school located on a 125 acre property in Somerset Valley, Pennsylvania, a wealthy suburb northwest of Pittsburgh, Pennsylvania. It is affiliated with the US Army and, accordingly, requires students to participate in a Junior ROTC program. It is an educational corporation established under a certificate of incorporation issued by the State of Pennsylvania in 1918. It has an approximate enrollment of 400 students and is supported by tuition and related fees, contributions, and income from endowment investments. The annual tuition, excluding fees, is $\$ 26,000$ per year.

The school has a history of high academic standards and consistently has gotten its graduates into the various military academies, as well as some of the finest colleges and universities in the country including sending a number of students to Ivy League universities each year. Its alumni are very successful and many have achieved recognition in medicine, law, investment banking, accounting, and sundry other professions. Its alumni include prominent military professionals, college professors, judges, partners in CPA and law firms, famous surgeons, and TV personalities. Moreover, the alumni are very involved in the school's activities and are very appreciative of the education they received. Accordingly, they give back handsomely to the school.

\section{PRESENT SITUATION}

The school has been audited by a large national accounting firm who also prepared the annual Form 990 (annual report for not-for-profit organizations). Since the Board has had much confidence in the ability of the firm performing the audit, the Board of Trustees has operated as a "rubber stamp" board and merely reviewed the financial statements, approved the budget for the following year, and made a number of minor recommendations.

During the year, several new members were appointed to the Board of Trustees. These new Board members come from Fortune 500 companies and are heavily involved with provisions of Sarbanes Oxley. Even though the Sarbanes Oxley Act does not apply to not-for-profit organizations, they became concerned with the number of years (30) that the firm has been auditing the school. They were also concerned with the general complacency on the Board. As a result, they decided to ask for audit proposals for the next audit. Similar to industry, they formed a separate Finance committee consisting of five Board members. The charge of the committee was to meet periodically with the Director of Finance, meet with the auditors upon completion of the audit (exit conference) and report findings to the Board of Directors. They would also play an integral role in selecting new auditors. Presently the Investment committee handled these duties. 


\section{ADMIRAL FURMAN ACADEMY STATEMENTS OF FINANCIAL POSITION FOR THE YEARS ENDED AUGUST 31, 2008 AND 2007}

\begin{tabular}{|c|c|c|c|c|}
\hline & & 2008 & & 2007 \\
\hline & & Temporaily & & Comparative \\
\hline & Unrestricted & Restricted & Total & Totals \\
\hline Assets & & & & \\
\hline Cash and cash equivalents & $\$ 1,143,188$ & 869,231 & $\$ 2,012,419$ & $\$ 1,590,200$ \\
\hline Short-term investments & 1,805 & 12,438 & 14,243 & 15,306 \\
\hline Tuition receivable, net of allowance for & & & & \\
\hline uncollectible accounts of $\$ 50,000$ and $\$ 63,000$ & 153,336 & - & 153,336 & 110,116 \\
\hline Other receivables & 549,900 & - & 549,900 & 285,468 \\
\hline $\begin{array}{l}\text { Promises to give receivable, less allowance for } \\
\text { uncollectible accounts of } \$ 235,000\end{array}$ & & & & \\
\hline and $\$ 250,000$ (Note 3) & - & $4,563,618$ & $4,563,618$ & $5,060,383$ \\
\hline Inventories & 78,881 & & 78,881 & 97,992 \\
\hline Prepaid expenses & 404,331 & & 404,331 & 309,945 \\
\hline Investment securities (Note 4) & & $25,669,838$ & $25,669,838$ & $26,858,748$ \\
\hline Beneficial interest in charitable trusts (Note 5) & - & 101,300 & 101,300 & 336,000 \\
\hline Premises and equipment (Note 6) & $33,897,090$ & & $33,897,090$ & $34,523,729$ \\
\hline Due from (to) other funds & 330,191 & $(330,191)$ & - & - \\
\hline Total Assets & $\$ 36,558,722$ & $\$ 30,886,234$ & $\$ 67,444,956$ & $\$ 69,187,887$ \\
\hline Liabilities and Net Assets & & & & \\
\hline Liabilities-- & & & & \\
\hline Accounts payable & 103,395 & $\$$ & 103,395 & 137,594 \\
\hline Accrued expenses & 519,187 & - & 519,187 & 544,865 \\
\hline Accrued severance benefits (Note 7) & 270,023 & - & 270,023 & 581,419 \\
\hline Deferred income and other liabilities & 464,206 & 50,000 & 514,206 & 534,382 \\
\hline Total Liabilities & $1,356,811$ & 50,000 & $1,406,811$ & $1,798,260$ \\
\hline Net Assets (Note 8) & $35,201,911$ & $30,836,234$ & $66,038,145$ & $67,389,627$ \\
\hline Total Liabilities and Net Assets & $\$ 36,558,722$ & $\$ 30,886,234$ & $\$ 67,444,956$ & $\$ 69,187,887$ \\
\hline
\end{tabular}




\section{ADMIRAL FURMAN ACADEMY \\ STATEMENTS OF ACTIVITIES \\ FOR THE YEARS ENDED AUGUST 31, 2008 AND 2007}

Exhibit B

\begin{tabular}{|c|c|c|c|c|}
\hline & & 2008 & & 2007 \\
\hline & & Temporaily & & Comparative \\
\hline & Unrestricted & Restricted & Total & Totals \\
\hline Changes in Net Assets-- & & & & \\
\hline Revenues and Support- & & & & \\
\hline Gross tuition and fees, net of tuition & & & & \\
\hline assistance of $\$ 1,709,699$ and $\$ 1,295,538$ & $\$ 8,400,844$ & \$ & $\$ 8,400,844$ & $6,384,863$ \\
\hline Student activities & 100,466 & - & 100,466 & 78,085 \\
\hline Fund raising-- & & & & \\
\hline Annual fund and other gifts & $2,493,552$ & - & $2,493,552$ & $2,012,693$ \\
\hline Endowment and capital campaign & & 540,674 & 540,674 & $4,959,121$ \\
\hline Alumni activities and parents' events & 198,691 & - & 198,691 & 205,065 \\
\hline Auxiliary programs & $1,048,837$ & - & $1,048,837$ & 739,602 \\
\hline Investment income (Note 4) & 52,229 & $(1,517,470)$ & $(1,465,241)$ & $4,048,272$ \\
\hline Change in value of charitable trusts (Note 5) & - & 6,915 & 6,915 & 93,000 \\
\hline Net assets released from restrictions & $1,426,122$ & $(1,426,122)$ & - & - \\
\hline Total Revenues and Support & $13,720,741$ & $(2,396,003)$ & $11,324,738$ & $18,520,701$ \\
\hline Expenses-- & & & & \\
\hline Instruction & $6,339,678$ & - & $6,339,678$ & $6,944,106$ \\
\hline Alumni and fund raising & 878,388 & - & 878,388 & 877,398 \\
\hline Operations and maintenance & $1,462,787$ & - & $1,462,787$ & $1,359,534$ \\
\hline Student activities & 576,443 & - & 576,443 & 539,563 \\
\hline Auxiliary programs & 369,332 & - & 369,332 & 359,826 \\
\hline General and administration & $2,013,799$ & - & $2,013,799$ & $1,838,525$ \\
\hline Depreciation & $1,035,793$ & - & $1,035,793$ & $1,159,215$ \\
\hline Total Expenses & $12,676,220$ & - & $12,676,220$ & $13,078,167$ \\
\hline Changes in Net Assets Before Transfers & $1,044,521$ & $(2,396,003)$ & $(1,351,482)$ & $5,442,534$ \\
\hline Transfer for depreciation & $(140,000)$ & 140,000 & - & - \\
\hline Transfer FY '07 excess annual fund & $(282,820)$ & 282,820 & - & - \\
\hline Transfer for special projects & $(256,239)$ & 256,239 & - & - \\
\hline Changes in Net Assets After Transfers & 365,462 & $(1,716,944)$ & $(1,351,482)$ & $5,442,534$ \\
\hline Net Assets - Beginning of Year & $34,836,449$ & $32,553,178$ & $67,389,627$ & $61,947,093$ \\
\hline Net Assets - End of Year & $\$ 35,201,911$ & $\$ 30,836,234$ & $\$ 66,038,145$ & $\$ 67,389,627$ \\
\hline
\end{tabular}




\section{ADMIRAL FURMAN ACADEMY \\ STATEMENTS OF CASH FLOWS \\ FOR THE YEARS ENDED AUGUST 31, 2008 AND 2007}

\section{Cash Flows From Operating Activities}

Changes in net assets

Adjustments to reconcile change in net assets to net cash provided by operating activities--

Depreciation

Provision (credit) for uncollectible tuition

Provision (credit) for uncollectible promises to give

Realized gains on investment securities

Unrealized (gains) losses on investment securities

Change in value of charitable trusts

Net change in operating assets and liabilities--

Short-term investments

Tuition and other receivables

Promises to give receivable

Inventories

Prepaid expenses

Accounts payable

Accrued expenses

Accrued severance benefits

Deferred income and other liabilities

Net Cash Provided by Operating Activities

Cash Flows From Investing Activities

Net increase to long-term investments

Capital improvements

Net Cash Used by Investing Activities

Increase in Cash and Cash Equivalents

Cash and Cash Equivalents, beginning of Year

Cash and Cash Equivalents, end of Year
2008

2007

$\$(1,351,482)$

$1,035,793$

$(13,000)$

$(15,000)$

$(11,980)$

$2,284,687$

234,700

1,063

$(294,652)$

511,765

19,111

$(94,386)$

$(34,199)$

$(25,678)$

$(311,396)$

$(20,176)$

$1,915,170$

$(1,083,797)$

$(409,154)$

$(1,492,951)$

422,219

$1,590,200$

$\$ \quad 2,012,419$
$\$ 5,442,534$

$1,159,215$

$(19,000)$

(4,592)

$(3,317,402)$

$(93,000)$

(12,738)

$(27,079)$

$(3,434,337)$

6,200

$(56,325)$

214

57,846

581,419

141,708

424,663

(1,469,884)

$(798,809)$

$(2,268,693)$

$(1,844,030)$

$3,434,230$

$\$ \quad 1,590,200$

The accompanying notes are an integral part of these financial statements. 
In March, 2008, the Finance Committee sent out a Request for Audit Proposal for the year ending August 31, 2008 to several CPA firms who concentrate on not-for-profit organizations, particularly, schools. The Board decided to entertain proposals from the "Big Four" and several national firms and regional firms. They recognized that there were a number of good lower tier firms who perform good work at reasonable fees. After interviewing a number of firms, the Finance Committee recommended the Pittsburgh firm of Biltmore, Norris, Johnson and Co.

The basic reasons for the Board's selecting BNJ \& Co. was due to the resources available, their experience in the field, particularly private schools, and the reasonableness of the fee. However, the Board also was quite impressed with their analyses of the prior year's financial statements. The Board members felt that of all the firms interviewed, they appeared to quickly grasp some of the intricacies of the engagement. Both BNJ \& Co.'s partner and manager felt that the footnotes could be more "user friendly", namely, written in a language that laymen could understand.

Since the school has a competent financial staff, it was agreed to commence the audit on or around October 1. The audit engagement went well and on November 30, the auditors had an exit conference with the Finance Committee to present a draft of the audit report. Attached are drafts of the basic financial statements, namely, Statements of Financial Position (Exhibit A), Statements of Activities (Exhibit B), and Statements of Cash Flows (Exhibit C).

Following are facts that relate to the financial statements that the auditors obtained during the engagement as they gathered different types of evidence including references to selected memos and schedules (Statements 1 thru 11) extracted from the auditors' workpapers:

1. The school is an educational corporation established under a certificate of incorporation issued by the State of Pennsylvania in 1918. It has an approximate enrollment of 400 students and is supported by tuition and related fees, contributions, and income from endowment investments.

2. Certain significant policy issues have to be addressed in the financial statements, including basis of accounting and use of estimates, basis of presentation, Federal and State income taxes, donor-imposed restrictions, cash and cash equivalents, concentration of credit risk, accounts and promises to give receivables, investment securities, premises and equipment, and revenue recognition among others.

3. The school's cash is held by Somerset Bank, which is a high quality financial institution in Western Pennsylvania and Ohio.

\begin{tabular}{lrr} 
Actual Balances per bank at August 31, 2008-- & \\
Cash - Operating - Somerset Bank & $\$ \quad 289,950$ \\
Cash - Payroll - Somerset Bank & & 20,000 \\
Cash - Money Management - Somerset Bank & 803,000 \\
\cline { 2 - 3 } & $\$ 1,112,950$ \\
\hline \hline
\end{tabular}

4. Depreciation expense is calculated using the straight-line method. The school has been using a useful life of 30 years for buildings and building improvements and 3-7 years for furniture and equipment.

5. Information from a schedule in the audit workpapers relating to promises to give receivables is as follows- 
Expected to be collected in--

Less than one year

One to five years

Thereafter

Less--

Allowance for uncollectible promises to give

Discount to present value at 5\%

Net Promises to Give

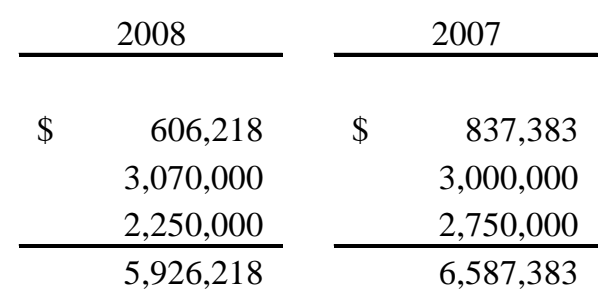

$(235,000)$

$(1,127,600)$

$(1,277,000)$

$5,060,383$

6. The school investments are in a family of mutual funds with a high quality financial institution. Information from a schedule in the audit workpapers relating to investment securities is as follows-

\begin{tabular}{|c|c|c|c|c|}
\hline \multirow[b]{2}{*}{ Fixed income } & \multicolumn{2}{|r|}{2008} & \multicolumn{2}{|r|}{2007} \\
\hline & $\$$ & $13,676,242$ & $\$$ & $14,669,816$ \\
\hline Equities & & $11,993,596$ & & $12,188,932$ \\
\hline Total & $\$$ & $25,669,838$ & $\$$ & $26,858,748$ \\
\hline
\end{tabular}

Fair value versus cost information taken from the audit workpapers is as follows-

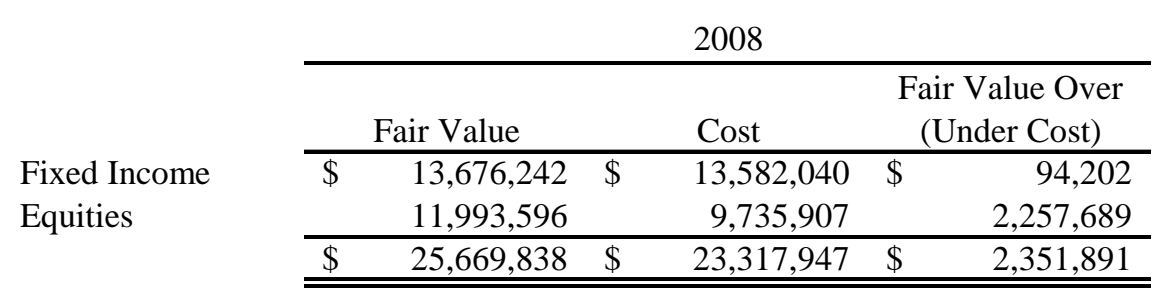

Fixed Income

2007

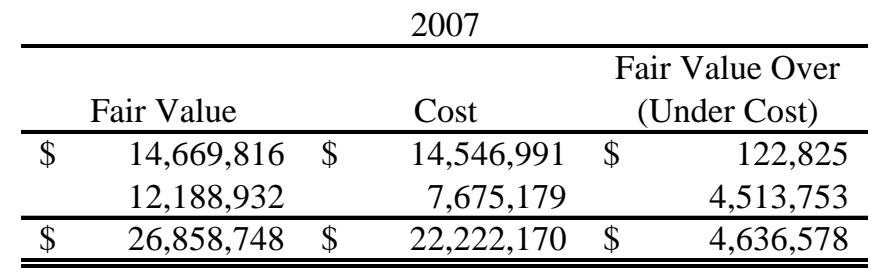

An analysis of investment returns taken from a workpaper schedule indicated that interest and dividends income for 2008 and 2007 were $\$ 807,466$ and $\$ 726,278$ respectively. Realized gains were $\$ 11,980$ and $\$ 4,592$ respectively. Unrealized gains in 2007 were $\$ 4,048,272$.

7. The audit workpapers included a schedule along with supplemental information relating to the school's beneficial interest in charitable trusts. An explanation on the schedule was as follows-

"As of August 31, 2007 (see last year's workpapers), the school was the irrevocable beneficiary of two charitable trusts valued at $\$ 336,000$ that were subject to certain split interest agreements. During the year one of the donors died and the school received a distribution of $\$ 241,615$ from the trust. At August 31, 2008 , the value of the school's beneficial interest in the remaining trust is $\$ 101,300$ (see schedule T-1). Note that the discount rate used is 5\%." 
8. A staff accountant vouched fixed asset additions and verified the calculation of depreciation. Her workpaper schedule indicated the following information.

At August 31, 2007, the cost of the land, building and building improvements, and furniture and equipment were $\$ 13,000,000, \$ 33,697,416$, and $\$ 2,796,890$. Accumulated depreciation at August 31, 2007 was $\$ 14,970,667$. The staff accountant satisfied herself as to the propriety of the capital additions during the year and the calculation of depreciation. Her workpapers indicated that the school spent $\$ 219,462$ on building improvements and $\$ 189,692$ on furniture and equipment upgrades. In addition, the school abandoned (scraped) $\$ 73,051$ of fully depreciated computer equipment during the year.

9. An audit workpaper in the liability area indicated that the school had entered into severance agreements with seven faculty members at the end of fiscal 2007. An agreement was reached to pay the teachers a percentage of their regular salary in addition to providing medical coverage to age 65 . This workpaper contained the following information developed by one of the staff accountants-

\section{Admiral Furman Academy \\ Calculation of Severance Pay Payable \\ Audit Y/E August 31, 2008}

\begin{tabular}{|c|c|c|c|c|c|c|}
\hline \multirow{5}{*}{ Balance - August 31, 2007} & \multirow{5}{*}{$\begin{array}{l}\text { (Salaries) } \\
\text { (FICA) } \\
\text { (Benefits) }\end{array}$} & \multirow[b]{2}{*}{ Instruction } & \multirow[b]{2}{*}{ Military } & \multirow{2}{*}{$\begin{array}{c}\text { Payable } \\
\text { @ 08/31/07 }\end{array}$} & \multicolumn{2}{|c|}{ To Be Paid In } \\
\hline & & & & & 07-'08 & 08-'09 \\
\hline & & $346,940.00$ & $50,004.00$ & $396,944.00$ & $218,715.00$ & $178,229.00$ \\
\hline & & $26,543.00$ & $3,826.00$ & $30,367.00$ & $16,732.00$ & $13,635.00$ \\
\hline & & $135,573.00$ & $31,393.00$ & $166,966.00$ & $88,807.00$ & $78,159.00$ \\
\hline & & $509,056.00$ & $85,223.00$ & $594,277.00$ & $324,254.00$ & $270,023.00$ \\
\hline Present Value Factor @ 5\% & & & & & 1.000000 & 0.952381 \\
\hline Present Value & (Salaries) & 0.87 & 0.13 & $388,457.00$ & $218,715.00$ & $169,742.00$ \\
\hline & (FICA) & 0.87 & 0.13 & $29,718.00$ & $16,732.00$ & $12,986.00$ \\
\hline & (Benefits) & 0.81 & 0.19 & $163,244.00$ & $88,807.00$ & $74,437.00$ \\
\hline & & & & $581,419.00$ & $324,254.00$ & $257,165.00$ \\
\hline
\end{tabular}

Discount @ 5\%

$12,858.00$

10. The audit workpapers revealed that the school did not have any assets that were permanently restricted. However, discussions with the Vice-President of Advancement and review of donor files and fund raising records including pledge cards indicated the following -

Capital improvements

Faculty benefits

Military summer camp program

Scholarship assistance

Beneficial interest in charitable trusts

Total

\begin{tabular}{|c|c|c|c|}
\hline \multicolumn{2}{|r|}{2008} & \multicolumn{2}{|r|}{2007} \\
\hline$\$$ & $5,092,970$ & $\$$ & $4,993,208$ \\
\hline & $2,727,010$ & & $3,165,864$ \\
\hline & 347,337 & & 397,602 \\
\hline & $22,567,617$ & & $23,660,504$ \\
\hline & 101,300 & & 336,000 \\
\hline$\$$ & $30,836,234$ & $\$$ & $32,553,178$ \\
\hline
\end{tabular}

In addition, the auditors indicated in their workpapers that the school released assets from restrictions for the following purposes in 2008

Capital improvements (\$476,122 as compared to $\$ 700,000$ in 2007 ); Scholarships (\$730,000 as compared to $\$ 640,000$ in 2007 ); Faculty benefits $(\$ 200,000$ as compared to $\$ 250,000$ in 2007 ; and Military summer camp program ( $\$ 20,000$ as compared to $\$ 30,000$ in 2007$)$. 
11. The auditor sent a legal confirmation to the school's attorneys. The response indicated that there were no lawsuits of a material nature.

\section{INSTRUCTIONS}

Review Statements of Financial Standards \#116, (Accounting for Contributions Received and Contributions Made), \#117 (Financial Statement Format), \#157 (Fair Value Measurement), and the AICPA Audit and Accounting Guide (Not-for-Profit Organizations). Accordingly, analyze the three basic financial statements and additional information provided from the auditors' workpapers and answer the following-

What footnotes should be required in order to make the financial statements complete and provide full disclosure to the financial statement reader? Draft the footnotes that you think best complement the financial statements.

\section{TEACHING NOTES}

The best way for students to start this case is to review the financial statements carefully, particularly the auditors' references to footnotes. This will tell the students where footnotes are certainly needed. Students should then determine based on their knowledge of accounting theory what other disclosures about the organization and significant accounting policies are required.

The students should familiarize themselves with the main items addressed in FAS \#116, \#117, and \#157 in addition to the AICPA Audit and Accounting Guide, Not-for-Profit Organizations?

Using the information provided in the case developed from the auditors' workpapers, the students should then prepare footnotes to complement the three financial statements provided in the case.

The suggested notes are as follows:

\section{ADMIRAL FURMAN ACADEMY NOTES TO FINANCIAL STATEMENTS AUGUST 31, 2008 AND 2007}

\section{Organization}

Admiral Furman Academy is a private all male military college preparatory high school.. It is affiliated with the US Army and, accordingly, requires students to participate in a Junior ROTC program. It is an educational corporation established under a certificate of incorporation issued by the State of Pennsylvania in 1918. It has an approximate enrollment of 400 students and is supported by tuition and related fees, contributions, and income from endowment investments.

\section{Summary of Significant Accounting Policies}

- Basis of Accounting and Use of Estimates

The accompanying financial statements are prepared on the accrual basis of accounting. The preparation of these financial statements requires management to make estimates and assumptions that affect the reported amounts of assets and liabilities and disclosure of contingent assets and liabilities at the date of the financial statements and reported amounts of revenues and expenses during the reporting period. Actual amounts could differ from these estimates.

\section{- Basis of Presentation}

The school follows established standards for external financial reporting by not-for-profit organizations. Accounting standards require that unconditional promises to give be recorded as receivables and revenues and require the organization to distinguish between contributions received for each net asset category in accordance with donor imposed restrictions. Conditional promises to give are recognized when the 
conditions on which they depend are substantially met. The three net asset categories are unrestricted net assets, temporarily restricted net assets and permanently restricted net assets.

Unrestricted net assets have no donor-imposed restrictions.

Temporarily restricted net assets have donor-imposed restrictions that are satisfied either by the passage of time or expenditures that meet the donor-specified purpose.

Permanently restricted net assets have donor-imposed restrictions that do not expire.

\section{- Income Taxes}

The school is exempt from Federal and State taxes pursuant to Section 501(c)(3) of the Internal Revenue Code as an educational entity.

\section{- Expiration of Donor-Imposed Restrictions}

The expiration of a donor-imposed restriction on a contribution or on endowment income is recognized in the period in which the restriction expires and at that time the related resources are reclassified to unrestricted net assets. A restriction expires when the stipulated time has elapsed, when the stipulated purpose for which the resource was restricted has been fulfilled, or both. In addition, the school follows the policy of reporting donor-imposed restricted contributions and endowment income whose restrictions are met within the same fiscal year as unrestricted support.

\section{- Cash and Cash Equivalents}

The school considers all highly liquid investments with a maturity of three months or less when purchased to be cash equivalents.

\section{- Concentration of Credit Risk}

The school maintains its regular and restricted cash balances and certificates of deposit with one highly respected financial institution. However, these deposits at times exceed the Federal Deposit Insurance Corporation (FDIC) insurance limit. As of August 31, 2008, the school's balances on deposit with this financial institution were $\$ 862,950$ in excess of the FDIC insurance limits of $\$ 250,000$ which became effective in October, 2008.

Concentration of credit risk associated with investment securities is considered low due to the credit quality of the financial institution holding these investments.

\section{- Accounts and Promises to Give Receivable}

The school provides allowances for doubtful receivables equal to the estimated collection losses that will be incurred in collection of all receivables. The estimated losses are based on historical collection experience coupled with a review of the current status of the existing receivables, including promises to give.

\section{- Investment Securities}

Investment securities are recorded at fair value. The fair value of equity and debt securities is based on the quoted market value of the underlying securities. Gains and losses are realized as of the trade date for investments.

\section{- Premises and Equipment}

Acquisition of land, buildings, improvements, and equipment are stated at cost, or at the fair value at date of contribution if acquired by gift. Donated services related to the school's construction projects are capitalized at the fair value of such services. Depreciation expense has been computed using the straightline method. Estimated useful lives of the school's premises and equipment are as follows: 
Building and building improvements Furniture and equipment $\underline{\text { Years }}$

30

$3-7$

\section{- Revenue Recognition}

The school records tuition and related fees as services are rendered through the academic year. Payments received in advance prior to August 31 which relate to the subsequent year are included in deferred income and other liabilities in the accompanying statement of financial position.

\section{Promises to Give Receivable}

These amounts, less an appropriate allowance for uncollectible promises, are recorded at their estimated fair value with amounts due later than one year at the present value of estimated future cash flows. Promises to give receivable at August 31 are as follows:
Expected to be collected in--
Less than one year
One to five years
Thereafter

Less--

Allowance for uncollectible promises to give

Discount to present value at $5 \%$

Net Promises to Give

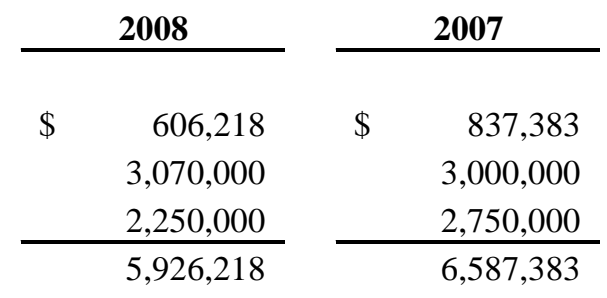

\begin{tabular}{|c|c|c|c|}
\hline & $(235,000)$ & & $(250,000)$ \\
\hline$\$$ & $4,563,618$ & & $5,060,383$ \\
\hline
\end{tabular}

\section{Investment Securities}

The school investments are in a family of mutual funds with a high quality financial institution. An analysis of the school's investment securities by at August 31 is as follows:

\begin{tabular}{|c|c|c|c|c|}
\hline \multirow[b]{2}{*}{ Fixed income } & \multicolumn{2}{|r|}{2008} & \multicolumn{2}{|r|}{2007} \\
\hline & $\$$ & $13,676,242$ & $\$$ & $14,669,816$ \\
\hline Equities & & $11,993,596$ & & $12,188,932$ \\
\hline Total & $\$$ & $25,669,838$ & $\$$ & $26,858,748$ \\
\hline
\end{tabular}

2008

Fixed Income

Equities

\begin{tabular}{|c|c|c|c|c|}
\hline \multicolumn{2}{|c|}{ Fair Value } & \multicolumn{2}{|r|}{ Cost } & $\begin{array}{c}\text { Fair Value Over } \\
\text { (Under Cost) }\end{array}$ \\
\hline$\$$ & $13,676,242$ & $\$$ & $13,582,040$ & $\$ \quad 94,202$ \\
\hline & $11,993,596$ & & $9,735,907$ & $2,257,689$ \\
\hline$\$$ & $25,669,838$ & $\$$ & $23,317,947$ & $2,351,891$ \\
\hline
\end{tabular}

2007

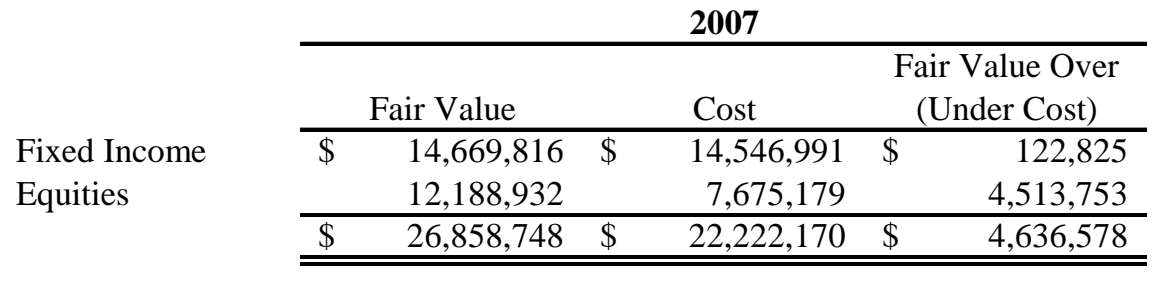


An analysis of investment returns, including interest on certain bank balances, for the years ended August 31 are as follows:

Interest/Dividends-Mutual Funds

Realized Gain (Loss)

Unrealized Gain (Loss)

\begin{tabular}{lrrr} 
& \multicolumn{2}{c}{$\mathbf{2 0 0 8}$} & \multicolumn{1}{l}{$\mathbf{2 0 0 7}$} \\
\hline$\$$ & 807,466 & $\$$ & 726,278 \\
& 11,980 & & 4,592 \\
& $(2,284,687)$ & $3,317,402$ \\
\hline$\$$ & $(1,465,241)$ & $\$$ & $4,048,272$ \\
\hline \hline
\end{tabular}

\section{Beneficial Interest in Charitable Trusts}

At August 31, 2007 the school was the irrevocable beneficiary of two charitable trusts valued at $\$ 336,000$ that were subject to a certain split-interest agreements. During the year, one of the donors died; accordingly, the school received a distribution of $\$ 241,615$ from the trust. At August 31, 2008, the value of the school's beneficial interest in the remaining trust is $\$ 101,300$, which has been calculated on a present value basis using a 5\% discount rate and the estimated mortality of the applicable donor.

\section{Premises and Equipment}

An analysis of premises and equipment as of August 31 is as follows:

\section{Land}

Building and building improvements

Furniture and equipment

\begin{tabular}{|c|c|c|c|}
\hline \multicolumn{2}{|r|}{2008} & \multicolumn{2}{|r|}{2007} \\
\hline$\$$ & $23,000,000$ & $\$$ & $23,000,000$ \\
\hline & $24,916,878$ & & $24,697,416$ \\
\hline & $1,913,621$ & & $1,796,980$ \\
\hline & $49,830,499$ & & $49,494,396$ \\
\hline & $(15,933,409)$ & & $(14,970,667)$ \\
\hline$\$$ & $33,897,090$ & $\$$ & $34,523,729$ \\
\hline
\end{tabular}

\section{7. $\quad$ Accrued Severance Benefits}

During 2007, the school entered into severance agreements with seven faculty members. Accordingly, the school has agreed to pay these individuals a percentage of their regular salary in addition to providing medical coverage until the age of 65 .

Severance benefits expected to be paid in --

Less than one year

One to two years

Less - discount at 5\%

Net Amount Payable

\begin{tabular}{|c|c|c|c|}
\hline \multicolumn{2}{|c|}{2008} & \multicolumn{2}{|c|}{2007} \\
\hline$\$$ & 270,023 & $\$$ & 324,254 \\
\hline & - & & 270,023 \\
\hline & 270,023 & & 594,277 \\
\hline & - & & $(12,858)$ \\
\hline$\$$ & 270,023 & $\$$ & 581,419 \\
\hline
\end{tabular}

8. Net Assets

Temporarily Restricted Nets Assets--

At August 31, temporarily restricted net assets consist of the following: 
Capital improvements

Faculty benefits

Military summer camp program

Scholarship assistance

Beneficial interest in charitable trusts Total

\begin{tabular}{|c|c|c|c|}
\hline \multicolumn{2}{|r|}{2008} & \multicolumn{2}{|r|}{2007} \\
\hline$\$$ & $5,092,970$ & $\$$ & $4,993,208$ \\
\hline & $2,727,010$ & & $3,165,864$ \\
\hline & 347,337 & & 397,602 \\
\hline & $22,567,617$ & & $23,660,504$ \\
\hline & 101,300 & & 336,000 \\
\hline$\$$ & $30,836,234$ & $\$$ & $32,553,178$ \\
\hline
\end{tabular}

During the years ended August 31, temporarily restricted net assets were released from restrictions in fulfillment of the following:

Capital improvements

Scholarships

Faculty benefits

Military summer camp program

\begin{tabular}{|c|c|c|c|}
\hline \multicolumn{2}{|r|}{2008} & \multicolumn{2}{|r|}{2007} \\
\hline$\$$ & 476,122 & $\$$ & 700,000 \\
\hline & 730,000 & & 640,000 \\
\hline & 200,000 & & 260,000 \\
\hline & 20,000 & & 20,000 \\
\hline$\$$ & $1,426,122$ & $\$$ & $1,620,000$ \\
\hline
\end{tabular}

\section{Contingencies}

From time to time, the school may become involved in legal claims arising in the ordinary course of its activities. In the opinion of management, the outcome of any legal proceedings are covered by the school's insurance policies and accordingly, would not have a material effect on its financial position or results of operations.

\section{OTHER COMMENTS-}

Since the auditors met with the Finance Committee in November, 2008, the period subsequent to August 31,2008 was one of tremendous economic turmoil. Students should receive extra credit if they noted that possibly a subsequent event footnote would be appropriate to disclose that the school sustained unrealized losses of \$xxx, Xxx from August 31 to the last day of field work, say October 31, 2008. It is not impossible that one's investment portfolio could have decreased by $20 \%$ during this period, which would require disclosure in the financial statements. 